\title{
EFFECTS OF RELIGIOUS CELEBRITY ON DESTINATION EXPERIENCE: THE CASE OF SOLMOE SHRINE
}

\begin{abstract}
:
A wealth of academic research has devoted to examining the effects of secular celebrities rather than the effect of spiritual celebrities on consumption and travel experience. We aim to investigate the effects of a religious celebrity on how visitors perceive a destination as well as their pilgrimage experience. Our study has shown that the indirect effects of both celebrity trustworthiness and expertise on destination image and place attachment are robust. These results suggest that spirituality plays a crucial mediator through which visitors can close the gap between pilgrimage on the spiritual side and their consumption experience on the destination side.
\end{abstract}

Keywords:

Religious celebrity; spirituality; destination image, place attachment; eudaimonia; Pope Francis

Published in "International Journal of Tourism Research", 2020, vol. 22, no. 1, pp. 1-14, which should be cited to refer to this work.

DOI: $10.1002 / j \operatorname{jt} .2314$ 


\section{INTRODUCTION}

A celebrity is a famed and influential figure in the spotlight of a wide range of social domains from pop culture, sports, politics, business, to arts, to name a few (McCracken, 1989). Since celebrities draw a great deal of public interest and attention, they are likely to affect people's perception of a product or brand through substantiating its visibility and credibility (Agrawal \& Kamakura, 1995; Amos, Holmes, \& Strutton, 2008; Byrne, Whitehead, \& Breen, 2003; Misra \& Beatty, 1990). Underlying all these effects is celebrity endorsement, which is used in developing public beliefs in a product endorsed by a celebrity because of people's obsession with the celebrity (Glover, 2009; Pringle, 2004). A celebrity possesses a variety of cultural meanings that go beyond the celebrity himself or herself, and are further conveyed to a product or brand, thereby enriching the connotation of the product or brand in consumers' minds (Brierley 1995; McCracken 1989). While the celebrity does not transform the product or brand entirely, he or she is still able to influence people's decision-making through affecting their perception of the product and even altering their preference to it (Glover, 2009).

A wealth of academic research has been devoted to examining the effects of secular celebrities, such as movie stars, singers and elite athletes, through featuring them in advertising and commercials (Erdogan, 1999). Little attention has been paid to religious celebrities, or their impact on consumption in general and travel experience in particular. As a matter fact, their effects have been constantly evidenced by mass media (Bacon, Leger, \& Madhani, 2015; CNN, 2019). Among the most famed religious contemporaries would be Pope Francis, the 266th Pope of the Catholic Church. Across the globe not only are his trips a manifestation of his religious leadership, but they have also attracted hundreds of thousands of people, including other celebrities and non-believers, to embark on the journeys he undertook (Papal Visit, 2015). For instance, the Korean pilgrimage shrine in the Daejeon diocese, which the Pope visited in 2014, has seen a steady increase in tourist arrivals ever since (Choi, 2015). The Pope's visit has popularized the shrine from serving pilgrims to attract mass tourists, generating profound implications for destination development.

While previous studies showed that pilgrimage sites provide various chances for retreat, meditation, and healing (Gesler, 1996; Peelen \& Jansen, 2007), how the presence of religious celebrities would transform a destination perceived by visitors, and ultimately affect their behavior and wellbeing has gone largely underexplored. This study aims to investigate the effects of religious celebrities on how visitors perceive and experience a destination. We aim to bridge the gap between pilgrimage and religious celebrities on the spiritual side and visitor experience and wellbeing on the consumption side. This examination focuses on testing the effects of spirituality that is peculiar to religious celebrities on how visitors conceive, perceive and experience a destination. Since spirituality represents people's ultimate quest for meaning and fulfillment, we further test whether the eudaimonia of tourists is affected by their awareness of religious celebrities at a pilgrimage site. This study suggests the importance of religious celebrities in developing pilgrimage tourism, which would benefit not only devout pilgrims at international levels but also local communities such as residents, religious organizations and governments.

\section{LITERATURE REVIEW}




\subsection{Celebrity Trustworthiness, Expertise and Attractiveness}

The effectiveness of a celebrity endorsement is built on three dimensions, namely trustworthiness, expertise and attractiveness, since they are instrumental in affecting consequent consumer behavior (Amos et al., 2008; Kim, Lee, \& Prideaux, 2014; Magnini, Garcia, \& Honeycutt Jr, 2010; Ohanian, 1990, 1991; van der Veen \& Song, 2010, 2014). Considering the peculiarities of religious leaders, trustworthiness is at the heart of celebrity endorsement, which is an indiscerptible attribute that they possess in the eyes of their disciples and even of ordinary people as a favorable consequence of trust (Amos et al., 2008; Magnini et al., 2010). Various facets of trustworthiness, including honesty, integrity, and believability, can therefore be conveyed to consumers through the endorsement of a product, and thereby affect people's perception of the product (Amos et al., 2008; Erdogan, Baker, \& Tagg, 2001; Magnini et al., 2010). Celebrity expertise is made up of competency, expertness, qualification, mastery, and authoritativeness in the area where the celebrity is competent (Kim et al., 2014). Because such expertise is a reliable source of recommendation from the celebrity based on his/her professional skills, experiences, or knowledge, it affects people's decision-making, especially those who deeply admire the celebrity (Amos et al., 2008; Magnini et al., 2010).

Another relevant attribute is celebrity attractiveness, while differs from celebrity trustworthiness and expertise due to its multi-dimensional nature. Celebrity attractiveness entails not only physical attractiveness but also social and psychological attractiveness, such as a celebrity's personality traits and charisma (Amos et al., 2008; Erdogan, 1999). Previous research asserted that trustworthiness and expertise have positive effects on the effectiveness of celebrity endorsement in advertising products and building up brands (Chao, Wührer, \& Werani, 2005). However, Caballero, Lumpkin, and Madden (1989) found that celebrity attractiveness is of little effect on endorsement effectiveness. In addition, trustworthiness and expertise are, to some extent, reflected in a similar consciousness like believability, which also signifies a credible source of celebrity (Simpson \& Kahler, 1980; van der Veen \& Song, 2010, 2014). Therefore, the three attributes can be considered respectively. Celebrity's physical and personality features can be transferred from trustworthiness and expertise in affecting endorsement effectiveness. We argue that whether and to what extent celebrity attractiveness affects celebrity effectiveness depends on what constitutes celebrity attractiveness due to its multifaceted nature. If celebrity attractiveness is underpinned by the inherent trustworthiness and expertise, an association between celebrity attractiveness and effectiveness can be drawn. We therefore propose:

H1: Trustworthiness of celebrity positively affects attractiveness of celebrity.

$\mathrm{H} 2$ : Expertise of celebrity positively affects attractiveness of celebrity.

\subsection{Religious Celebrity and Spirituality}

Spirituality is a concept in questing the meanings of consumer behavior, yet it is underexplored largely due to the chasm between divine pilgrimage and worldly living (Piedmont, 2001; UlvoasMoal, 2010). It is spirituality that distinguishes between religious celebrities and their secure counterparts. Yet as a fabric of an individual's experience embedded in universal threads of religions, spirituality is the inner depth of one's psychological status (Piedmont, 1999), 
representing people's ultimate quest for and deep involvement in a religion (Gorsuch \& Shafranske, 1984). Thus, spirituality, if anything, would affect secular consumption at least for pilgrims and the like. Such effects are accomplished by what is called spiritual transcendence, suggesting an individual's ability to reflect his or her life from an objective perspective by standing outside his or her immediate sense of a time and place (Piedmont, 1999; 2001). Spiritual transcendence recognizes the limitedness of perspectives and considers a vision of life that satisfies more fundamental urges of nature (Piedmont, 1999).

However, unclear is what makes up the dimensions of spirituality that can account for religious tourism and tourist experience with pilgrimage destinations (Sharpley, 2009; Sharpley \& Sundaram, 2005). When it comes to religious celebrities, it is essential to advancing incumbent models of celebrity effects through articulating the associations between the three dimensions of celebrity effectiveness and spirituality. As long as the effects of religious celebrities are concerned, the model advancement helps better explain the role of spirituality in generic consumption and, in particular, tourist experience. We can thus articulate the role of a religious celebrity in popularizing pilgrimage sites as tourist destinations, as well as how the awareness of the celebrity's presence affects visitors' deep psychological status in tourism consumption. We therefore propose:

H3: Trustworthiness of celebrity positively affects spirituality.

H4: Expertise of celebrity positively affects spirituality.

H5: Attractiveness of celebrity positively affects spirituality.

\subsection{Celebrity Spirituality, Destination Image, and Place Attachment 2.3.1 Destination image and place attachment}

Destination image is tourists' cognitive and affective evaluations of a destination, including their knowledge, feelings and impressions associated with the destination (Baloglu \& McCleary, 1999; del Bosque \& San Martín, 2008; Li \& Stepchenkova, 2012). Studies show that the affective component of destination image is an antecedent of emotions and feelings attached to the destination (Prayag \& Ryan, 2012; Scannell \& Gifford, 2010; Williams \& Vaske 2003). Such place attachment indicates the extent to which individuals value the benefits that certain places provide in their travel experience (Moore \& Graefe, 1994), suggesting an emotional bond between individuals and the place they visited (Williams, Patterson, Roggenbuck, \& Watson, 1992). Therefore, it is hardly surprising that studies have found that a favorable destination image leads to strong place attachment (Kaplanidou, Jordan, Funk, \& Ridinger, 2012; Prayag \& Ryan, 2012; Veasna, Wu, \& Huang, 2013). Veasna et al. (2013) confirmed that destination image significantly influences the emotional part of destination attachment. Kaplanidou et al. (2012) found that destination image increases place attachment but highlighted that atmosphere and cultural characteristics of a destination are the important antecedents of place attachment. We propose:

H6: Destination image positively affects destination attachment.

\subsubsection{Celebrity endorsement on destination image and place attachment}


Celebrity endorsement is grounded in a strong linkage between celebrity image and product image in shaping consumer experience (Kamins \& Gupta, 1994; Misra \& Beatty, 1990; Till, Stanley, \& Priluck, 2008). A celebrity-endorsed product becomes preferred by consumers because a favorable celebrity image perceived by consumers is being transferred to the product, and thus updates consumer preference in the decision-making process (Petty \& Cacioppo, 1986). In particular, the two components of celebrity image, namely trustworthy and expertise are manifested in consumers' believability, indicating the valid and credible source of celebrity endorsement (Simpson \& Kahler, 1980; van der Veen \& Song, 2010, 2014). Kim et al. (2014) found that all three components of celebrity image influence corporate image of hotels, among which celebrity expertise is the most significant one. Since credible sources for endorsing tourist destinations are crucial (Erdem, Swait, \& Louviere, 2002; Veasna et al., 2013), celebrities play an important role in substantiating endorsement credibility, leading to a positive destination image (Glover, 2009; Lee, Scott, \& Kim, 2008; Yen \& Croy, 2016). We propose:

H7: Trustworthy of celebrity positively affects destination image.

H8: Expertise of celebrity positively affects destination image.

H9: Attractiveness of celebrity positively affects destination image.

Previous studies have examined the relationship between consumer involvement with a celebrity and their emotions attached to a place (Kim, 2012; Lee et al., 2008; Wong \& Lai, 2015). Among these studies, Lee et al. (2008) underscored the effects of consumer involvement with a celebrity on place perception. Their study found that consumers' familiarity with the destination is influenced by the extent to which they are involved with the celebrity. Kim (2012) found that audience, who are highly involved in a TV program that portrays their favorite celebrities, are more likely to affirm their emotional attachment to celebrity and eventually to tourist destinations. In other words, when people are emotionally attached to a certain celebrity, they feel strong intimacy and familiarity with the place that is related to the celebrity. This result was later confirmed by Wong and Lai (2015), who went on to articulate that people's attachment to a celebrity positively affects their attachment to a place pertinent to the celebrity.

When the sources for destination endorsement are credible, tourists remain attached to the destination (Veasna et al., 2013). Therefore, the level of place attachment can be amplified by the endorsement from celebrities simply because trustworthiness remains at the heart of celebrity image. As previous studies found that the attractiveness of a destination stems, in part, from celebrity endorsement for the destination, the meanings that a celebrity possesses can be transferred to the destination, and thus enhance place attachment (Kim, 2012; Lee et al., 2008; Wong \& Lai, 2015). In particular, tourists' strong emotional bond with a destination can be created under a circumstance in which a trip to the destination made by a favorite celebrity is considered as a type of pilgrimage (Lee et al., 2008; Ryan, Yanning, Huimin, \& Song, 2009). We propose:

H10: Trustworthy of celebrity positively affects destination attachment.

H11: Expertise of celebrity positively affects destination attachment.

H12: Attractiveness of celebrity positively affects destination attachment.

\subsubsection{Spirituality and pilgrimage destinations}


Religion has a significant effect on place attachment at sacred sites (Mazumdar \& Mazumdar, 2004). Given the importance of religion or religious activities in people's everyday lives, we can elicit the meaning of place through experiencing religious places and eventually facilitating devotion (Mazumdar \& Mazumdar, 2004). Yet the role of religion in creating personal meaning in a sacred space has been overlooked (Mazumdar \& Mazumdar, 2004). Thus, it is necessary to integrate personal meaning into the meaning of place at a spiritual level, thereby increasing the understanding of travel experience to a pilgrimage site. Studies show that spiritually committed consumers have a positive attitude toward consumption of goods and services in line with their spiritual values (Ulvoas-Moal, 2010). Since spirituality focuses on searching for existential meaning in life (Doyle, 1992; Piedmont, Ciarrochi, Dy-Liacco, \& Williams, 2009), it is "a way of being and experiencing that comes about through awareness of a transcendent dimension that is characterized by certain identifiable values in regard to self, life, and whatever one considers to be the Ultimate" (Elkins et al., 1988, p. 10). Because affective image is highly related to individuals' emotions and feelings about an object (Gartner, 1994; Holbrook, 1978), from the psychological aspect spirituality is an important antecedent of affective destination image. We therefore propose:

H13: Spirituality positively affects destination image.

H14: Spirituality positively affects destination attachment.

\subsection{Eudaimonia}

Spiritual transcendence emphasizes a search for connection with sacredness, which can be explained in three domains: connectedness, universality, and prayer fulfillment (Piedmont, 1999; 2001). According to Piedmont $(1999,2001)$, connectedness is a belief that a person belongs to a human orchestra whose contribution is essential to maintaining the harmony of life; universality is a unitive feature of life; and prayer fulfillment is an emotional state of joy and satisfaction derived from enlightenment with a transcendent reality. Spirituality in life emphasizes the affective side of humanity, the autonomous expressivity of an individual's life experience and experiential contact, which flow through other aspects of one's being to integrate, harmonize or balance the self (Heelas, 2009). Guo (2015) identified the model of spirituality as a reconceptualization of the self, containing the search for self-knowledge, adaptation of that knowledge, and the intellectual aspiration for self-transformation. Willson, McIntosh and Zahra (2013) investigated the process of how tourism provides travelers an opportunity to seek personal meaning in life and purposes of life in both religious and non-religious contexts. We propose:

H15: Spirituality positively affects eudaimonia.

H16: Destination image positively affects eudaimonia.

H17: Destination attachment positively affects eudaimonia.

\section{5 'Celebritization' of Religious Personalities}

Despite the fact that religious leaders have cemented the status of universal icons among their followers, there has been little research on the topic (Lanuza, 2017). A few studies have 
attempted to investigate the social and economic impacts of the 'celebritization' of religious personalities in various contexts (Bae, Brown, \& Kang, 2010; Barajas, Lago-Peñas, \& Sanchez, 2014; Brown, 2009; Lanuza, 2017). Although the process of celebritization is mainly associated with marketing strategies, Lanuza (2017) analyzed the current status of Pope Francis from the perspective of a social constructionist, concluding that unlike any other celebrities, the Pope is an icon that gives rise to the Catholic faith in the contemporary postmodern world. Specifically, the Pope was emphasized as a celebrity of people, whose commercial and sociocultural values are grounded in the long tradition of the Catholicism instead of a temporary fandom of spiritual customers. Because of these impacts, it was reported that the presence and trip of the Pope led to an increase of donation rate and mass attendance rate (Chua-Eoan, \& Dias, 2013).

We explain the celebritization of religious personalities in the tourism context based on McCracken's (1989) meaning transfer model. This model states that celebrity effectiveness is evaluated by how consumers associate the meaning of an endorser with a product and ultimately transfer them to the product. First, the cultural meaning of depth and power associated with a celebrity, including his status, class, and personality, are transferred to the product by the celebrity as an endorser. This meaning remains in people's mind, and eventually, the meaning of brand is attained (Erdogan, 1999). This model explicates the meaning transfer of the celebrity that affects consumer consumption. Second, a world culturally constituted by the celebrity moves into consumer products and eventually to the life of the consumer. That is, the celebrity is a core player in the process of meaning transfer. Although this study laid a foundation for meaning transfer of a celebrity, it is restricted to explaining consumer products. In the tourism context, we expand the endorsement process by including the assessment of the tourist experience as shown in Figure 1.

\section{[Insert Figure 1 here]}

\section{METHODS}

\subsection{Study Site}

Solmoe Shrine located in Dangjin city in the province of Chungcheong, South Korea, was selected as the site of the present study. Solmoe Shrine is known as the Bethlehem of Korea for being the birthplace of the first Korean Catholic priest "Saint Andrew Daegeon Kim." Chungcheong province was one of the regions where the doctrine of Catholicism was initially disseminated to Korea, and evolved as one of the earliest and largest faithful communities in Korea to embrace Catholicism in 1784-1785 (Solmoe Shrine, 2019). Therefore, not only is the Shrine recognized as a pilgrimage landmark also called "Martyrs' home" where eleven martyrs are celebrated, but it was also listed as the 529th National Register of Historic Place in Korea (Solmoe Shrine, 2019).

Pope Francis visited South Korea in 2014, mainly to beatify 124 Korean martyrs and celebrate Asia Youth Day (AYD), the biggest Catholic youth festival in the Asia Pacific region and was held in the Daejeon diocese in Korea. Solmoe Shrine was among the first sites during the Pope's Korea visit for the opening ceremony of the event. In fact, as a cultural exchange, the AYD festival itself attracted both local and international pilgrims. Shortly after his visit in 2014, the 
religious site gained in popularity, among both pilgrims and tourists. According to statistics published by Solmoe Shrine (2018), visitor numbers hit a record high during and immediately after the Pope's visit, with 153,000 visitors recorded in 2014 alone. While visitor numbers have leveled off ever since, the average in the recent four years doubled that of the pre-visit period (see Figure 2).

\section{[Insert Figure 2 here]}

Since the Pope's discipleship visit in 2014, the municipal government of Dangjin initiated an urban attraction development project in the surrounding area of the Shrine as part of a special district development in the city. Besides creating his statue, topiary, and mural, the 1.9-km long street surrounding the Shrine was named after the Pope (Choi, 2017). Since 2017 the Catholic Cultural Center of Korea along with Pope Francis's Plaza and historical park has been under construction, and will be established as the cultural and district of Solmoe Shrine designated by the Ministry of Culture, Sports and Tourism of Korea (Choi, 2017).

\subsection{Measurement Scales}

A total of seven constructs that specified the hypotheses were measured with multiple item scales adopted from previous studies. All the items were operationalized using a 7-point Likert scale, indicating 1 = totally disagree, $4=$ natural, to $7=$ totally agree. As for celebrity endorser, previous studies adopted diverse dimensions to measure celebrity image. Lee et al. (2008) and Yen and Croy (2016) adopted three dimensions of celebrity involvement, including attraction, centrality to lifestyle and self-expression. Two dimensions of attractiveness and believability were used by van der Veen and Song (2014) to measure the perceived image of a celebrity endorser. We followed Kim et al. (2014) to adopt three dimensions of celebrity image, namely trustworthiness, expertise and attractiveness. A 15-item measure of spirituality was used based on the measurement developed by Piedmont (1999), followed by eight items to measure the affective image of Solmoe Shrine (Baloglu \& McCleary, 1999; Echtner \& Ritchie, 1993). The items of destination image were measured on a 7-point bipolar scale. A 12-item measure of place attachment was based on Kyle, Graefe, and Manning (2005), and three items of eudaimonia was based on Chen and Li (2018). All the measurement items were extracted from previous studies and revised to adapt to the context of this study.

\subsection{Data Collection}

Since potential respondents were mainly Koreans, an English version of the questionnaire that consisted of the measurement and social demographics was first developed and then translated into the Korean language by a native researcher. Prior to conducting the main survey, a pilot test was conducted along with several interviews with priests and nuns living in the shrine to validate the measurement of the constructs. In the main survey, the questionnaire was administered to visitors at the shrine in May and June in 2018. Respondents were identified by asking two screening questions regarding their motivation and recognition of the Pope's visit to the Solmoe Shrine in 2014. To increase participation in the survey, each respondent who completed the survey was offered an incentive for appreciation. Of the 346 questionnaires collected, 337 were deemed valid for further data analysis. 


\section{RESULTS AND DISCUSSION}

\subsection{Profiles of Respondents}

Table 1 shows the sociodemographic profile of the respondents. Of the 337 respondents, more than three-fourths (75.1\%) were females. Over $50 \%$ of the respondents aged 60 or above, including over one-third (34.4\%) between 60 and 69 , and $16.6 \%$ above 70 years old, those below 40 years old only made up $10 \%$. Such a female- and elderly-dominance was has been as marked in other tourist behavior studies. Not surprisingly, a whopping $88.4 \%$ of the respondents were married, reflecting the age distribution. Respondents who had obtained a university education accounted for the largest (nearly 50\%), followed by those with a high school education $(30.3 \%)$. The distribution of occupation was strikingly uneven, with $52.2 \%$ of the respondents being civil servants, while the other nine occupations accounting for less than $10 \%$ each. We found that low-income respondents outnumbered their high-income counterparts, with $62 \%$ (below 4,001) versus $38 \%$ (above 4000). All the respondents exclusively reported that they were Roman Catholic. When asked to rate their level of religious belief, some $68 \%$ of the respondents stated that they were religious or very religious.

\section{[Insert Table 1 here]}

Table 2 shows the travel profile of the respondents visiting the Solmoe Shrine at the time of this survey. All respondents were aware that the Pope had visited the Solmoe Shrine in August 2014, of which $72.1 \%$ indicated that they knew the purpose of the Pope's visit. Around $44.5 \%$ and $38.3 \%$ of the respondents had heard of the Solmoe Shrine before and after the Pope's visit, respectively. Nearly $80 \%$ of the respondents acknowledged the site's historical importance. Approximately $54.3 \%$ of the respondents were repeat visitors. Pilgrimage (retreat) was the predominant travel purpose $(88.7 \%$ ) of the respondents, while tourism accounted for only $8.6 \%$. When asked about their travel motivations $(M>5.55)$, the respondents in general underlined the importance of religious celebrities in their decision to visit the Solmoe Shrine.

$$
\text { [Insert Table } 2 \text { here] }
$$

\subsection{Measurement Model}

Table 3 shows various criteria to assess the reliability of the seven constructs. All the factor loadings of the constructs were statistically significant and greater than the cutoff value of .70, suggesting that the indicators measured their corresponding constructs quite well (Bagozzi \& Yi, 1988; Hair et al., 2014). The Cronbach's $\alpha$ s of all constructs exceeded the threshold of .70 suggested by Nunnally (1978) and Nunnally and Bernstein (1994), indicating high internal consistency of the constructs. Due to Cronbach's $\alpha$ 's limitations, we adopted composite reliability to further assess the internal consistency of the constructs. The results showed high a level of internal consistency despite the assertion that a composite reliability of greater than 0.90 is not desirable in this regard (Hair et al., 2016). We also adopted the Rho_A defined by Dijkstra-Henseler to check the reliability of the constructs, and the values were above .70, suggesting high reliability. 
Table 4 shows various criteria to check the validity of the seven constructs. The average variance extracted (AVEs) of all constructs was above .50, (Fornell \& Larcker, 1981; Hair et al., 2014), indicating that satisfactory convergent validity was met. The square roots of all constructs' AVEs were larger than the corresponding inter-construct correlations, indicating the measurement model had satisfactory discriminant validity (Fornell \& Larcker, 1981; Hair et al., 2014). In addition, we adopted the heterotrait-monotrait ratio of correlations (HTMT) as an alternative method based on the HTMT ${ }_{90}$ criterion and the $\mathrm{HTMT}_{\text {inference }}$ in checking discriminant validity (Henseler, Ringle, \& Sarstedt, 2015), because the Fornell-Larcker criterion and the assessment of cross-loadings were criticized for their failure to detect discriminant validity (Henseler et al., 2015). Table 5 shows that there were only minor issues of discriminant validity (celebrity trustworthiness and celebrity expertise, celebrity trustworthiness and celebrity attractiveness, celebrity expertise and celebrity attractiveness), all were related to celebrity attractiveness. We therefore retained these constructs in the model for path analysis.

\section{[Insert Table 4 and 5 here]}

\subsection{Structural Model}

Table 6 shows the coefficients of the structural relationships and the corresponding confidence intervals. Of the 17 structural relationships in the model, nine were statistically significant at .05 , and the directions of the relationships were consistent with the hypotheses. The results show that $56.2 \%$ of the variance in eudaimonia was explained by all its predictors, $50.7 \%$ of the variance in destination attachment was explained by its predictors. Table 7 presents the $f^{2}$ values, which were used to assess the contribution of an exogenous construct to an endogenous construct's $R^{2}$. According to Hair et al. (2014) criteria, we found that three religious celebrity constructs as the predictors, namely celebrity trustworthiness, celebrity expertise and celebrity attractiveness, had negligible effects on endogenous variables of tourist behavior, namely destination image and destination attachment. Indeed, $f^{2}$ values were far below .02, which is the cutoff value to satisfy a small effect (Hair et al., 2014). By contrast, the effects of spirituality, a mediator in the model, were significant in explaining tourist-relevant behaviors as well as eudaimonia, with the $f^{2}$ values ranging between .052 and .500 . Also, destination image and destination attachment were found to have substantial effects in explaining eudaimonia, with the $f^{2}$ values at .025 and .325 , respectively.

\section{[Insert Table 6 and 7 here]}

On the one hand, we found compelling evidence for the effects of celebrity trustworthiness and celebrity expertise on celebrity attractiveness. Specifically, there were significantly positive associations between celebrity trustworthiness and celebrity attractiveness $(\beta=.470)$, celebrity expertise and celebrity attractiveness $(\beta=.219)$, celebrity expertise and spirituality $(\beta=.388)$. On the other hand, we found that the associations between behavioral constructs, namely destination image, destination attachment and eudaimonia, were significant positively, and that all three were affected by spirituality. Nevertheless, note that all the eight nonsignificant 
structural relationships in the model were the direct paths between religious constructs and behavioral constructs. These results suggest that tourists' experience and perception shaped by religious celebrities may have little to do with their behavioral patterns at the destination. This may explain why religious tourists, compared with other tourists, do not regard recreational tourist activities as important. This can be accounted for, in part, by their visiting purposes: we found that nearly $90 \%$ of the respondents were visiting in order to make a pilgrimage while tourism accounted for less than $10 \%$.

\subsection{Mediation Analysis}

We further examined the mediation effects of the three constructs in the model, namely celebrity attractiveness, spirituality and destination image. Except for celebrity attractiveness, the indirect effects between religious constructs and behavioral constructs were verified. Specifically, the total indirect effects of celebrity trustworthiness on destination image were statistically significant $(\beta=.172)$, suggesting the mediation effect of celebrity attractiveness in the model. We found that the total indirect effects of celebrity expertise on destination image $(\beta=.207)$ and on eudaimonia $(\beta=.236)$ were statistically significant. However, no indirect effects of celebrity attractiveness on all behavioral constructs were detected, suggesting that celebrity attractiveness is not a predictor of tourist behavior in the religious context. We found that all the indirect effects of spirituality were significant in the model, and the indirect effect of destination image on eudaimonia was also significant.

[Insert Table 8 here]

We further present specific indirect effects of the constructs in Table 9, which help articulate how the mediation effects were manifested in the model. In particular, the effect of celebrity trustworthiness on destination image was mediated by celebrity attractiveness, and spirituality was the mediator of the relationship between celebrity trustworthiness and destination attachment. We also detected a series of mediation effects from celebrity trustworthiness (CT) $\rightarrow$ spirituality (SP) $\rightarrow$ destination attachment (DA) $\rightarrow$ eudaimonia (EM), in which spirituality and destination attachment were two subsequent mediators in the model. When it comes to celebrity expertise, all the mediation effects were statistically significant. In particular, we found that spirituality was the most pronounced mediator in the model. Not only did spirituality mediate the effects of religious constructs on behavioral constructs, it also mediated the relationship between eudaimonia and its predictors. These results suggest the central role of spirituality in predicting tourist behavior in a religious context.

[Insert Table 9 here]

\section{CONCLUSION AND LIMITATIONS}

\subsection{Theoretical Implications}

This study aims to investigate the effects of religious celebrity on visitors' spirituality and destination experience. We established the associations between religious celebrities and the secular tourism consumption. On the religious side, we found strong relationships between the 
image of a religious celebrity (measured by trustworthiness and expertise) and spirituality, which is a key concept in examining the effects of religious celebrity. Spirituality depends much on trustworthiness and expertise of the celebrity but not on his/her attractiveness. As far as the effectiveness of celebrity endorsement is concerned, the results suggest a striking difference between secular celebrities and religious celebrities. Previous studies found that all three dimensions of celebrity image affected the image of, or even customer loyalty to, an endorsed product or company (Amos et al., 2008; Kim et al., 2014). The attractiveness of secular celebrities is manifested in the physical aspects of celebrities, such as appearance (Amos et al., 2008; Erdogan 1999). By contrast, spiritual leaders who have achieved celebrity status are barely influenced by these physical aspects (Bae et al., 2010).

On the destination side, we verified the well-established relationship between destination image and place attachment (Kaplanidou et al., 2012; Prayag \& Ryan, 2012; Veasna et al., 2013) concerning pilgrimage destination. While both destination image and place attachment affect eudaimonia, the effect of place attachment is much stronger. This is because place attachment underscores the internal emotional bond (Veasna et al., 2013) between tourists and the destination by which the meaning and fulfillment of tourist experience can be augmented.

We found that the direct relationships between religious celebrity and tourist experience associated with the pilgrimage destination are weak. In particular, no strong evidence was found for the direct effects of either celebrity trustworthiness or celebrity expertise on destination image and place attachment. The only significant association was between celebrity attractiveness and destination image. Previous studies argued that celebrity endorsement as a credible source for destinations contributes to building up destination image (Erdem et al., 2002; Veasna et al., 2013). However, our study suggests that neither the presence of religious celebrities at a destination nor visitors' awareness of their presence can be directly enhanced into experience with the destination.

\subsection{Practical Implications}

Unlike secular celebrities, religious celebrities propagate spiritual values in the contemporary world (Barajas et al., 2014; Lanuza, 2017). Pope Francis, for instance, has a great impact on sociocultural values of the society (Bae et al., 2010; Barajas et al., 2014; Brown, 2009). The visit of the Pope has become an extraordinary occasion for the Roman Catholic's 1.2 billion believers and even non-Catholics. The Pope has a positive impact on their emotional and spiritual perceptions, destination experiences and happiness. Being the highest leader of the Roman Catholic Church confers a significant status to the person occupying the position. However, not all popes become successful celebrities as many of them were well-known but did not achieve celebrity status. Although Pope Francis's presence and apostolic journeys have been highlighted as a celebrity culture that created the "spectacle" of Pope Francis, it should be distinguished from his charismatic prophetic message (Lanuza, 2017). Although the influence of religious celebrities is perhaps obscure in creating tourist experience, the indirect effects of both celebrity trustworthiness and expertise on destination image and place attachment are robust, in which spirituality plays a crucial mediating role.

Pilgrimage sites as religious destinations play a significant role in affecting spirituality and 
individuals' eudaimonia. In our study, Pope Francis's impact on pilgrims' spirituality and destination experience suggests a long-lasting cultural and experiential development of pilgrimage tourism. With increasing attention being paid to pilgrimage sites, the attractiveness of a destination, such as Solmoe Shrine, lies in the assertion that spirituality is as the ultimate value of life. It suggests the crucial role that religious celebrities play in destination development from a tourist's perspective. A deep understanding of the importance of celebrities in influencing destination image and place attachment can suggest a more proficient way toward destination sustainability. A religious shrine would offer spiritually fruitful opportunities for people from all over the world, and their experience with the shrine will enrich spirituality at the pilgrimage site as an ultimate value of life.

\subsection{Limitations and Future Research}

This study has a couple of limitations. First, it was an investigation of one particular shrine along with a single occasion of the Pope's visit. Therefore, the results of this study might not be generalized to other pilgrimage destinations and other religious celebrities. We therefore suggest that the model be tested at other pilgrimage sites with the presence of other religious celebrities. Second, compared to other recreational tourist destinations, a pilgrimage destination is rooted deep in its history and religious ideology; therefore, tourists' awareness of them, in addition to the presence of religious celebrities, should be investigated. Finally, a reverse causality may exist between spirituality and tourist experience, suggesting that tourists' pilgrimage experience and eudaimonia can lead to spirituality. Therefore, future researchers should factor the reverse causality into research design and model development. 


\section{REFERENCES}

Agrawal, J., \& Kamakura, W. A. (1995). The economic worth of celebrity endorsers: An event study analysis. Journal of Marketing, 59(3), 56-62.

Amos, C., Holmes, G., \& Strutton, D. (2008). Exploring the relationship between celebrity endorser effects and advertising effectiveness: A quantitative synthesis of effect size. International Journal of Advertising, 27(2), 209-234.

Bacon, J., Leger, D. L., \& Madhani, A. (Sept. 27, 2015). Hundreds of thousands flood Philly for Pope Francis' final Mass. USA TODAY. Retrieved from http://www.usatoday.com/story/news/2015/09/27/pope-francis-wraps-up-us-visitphiladelphia/72923820/

Bae, H. S., Brown, W. J., \& Kang, S. (2010). Social influence of a religious hero: the late Cardinal Stephen Kim Sou-hwan's effect on cornea donation and volunteerism. Journal of Health Communication, 16(1), 62-78.

Bagozzi, R. P., \& Yi, Y. (1988). On the evaluation of structural equation models. Journal of the Academy of Marketing Science, 16(1), 74-94.

Baloglu, S., \& McCleary, K. W. (1999). A model of destination image formation. Annals of Tourism Research, 26(4), 868-897.

Barajas, A., Lago-Peñas, S., \& Sanchez, P. (2014). On the regional economic effects of the Pope's journeys: evidence from the visit to Santiago de Compostela in 2010. Tourism Economics, 20(2), 279-299.

Brierley, S. (2005). The advertising handbook. London: Routledge.

Brown, W. J. (2009). Mediated Influence of Pope John Paul II. Journal of Communication \& Religion, 32(1), 33-61.

Byrne, A., Whitehead, M., \& Breen, S. (2003). The naked truth of celebrity endorsement. British Food Journal, 105(4/5), 288-296.

Caballero, M. J., Lumpkin, J. R., \& Madden, C. S. (1989). Using physical attractiveness as an advertising tool: An empirical test of the attraction phenomenon. Journal of Advertising Research, 29(4), 16-22.

Chao, P., Wührer, G., \& Werani, T. (2005). Celebrity and foreign brand name as moderators of country-of-origin effects. International Journal of Advertising, 24(2), 173-192.

Chen, Y., \& Li, R. (2018). Does a happy destination bring you happiness? Evidence from Swiss inbound tourism. Tourism Management, 65, 256-266.

Choi, K. S. (2015, February 02). Dangjin, promotion of an attraction of Solmoe Shrine where Pope Francis visited. ChungCheongilbo. Retrieved from http://www.ccdailynews.com/news/articleView.html?idxno=753033

Choi, K. S. (2017, August 06). Undertaking attraction development project of Solmoe Shrine. ChungCheongilbo. Retrieved from http://www.ccdailynews.com/news/articleView.html?idxno=933651.

Chua-Eoan, H., \& Dias, E. (2013). Person of the Year 2013: Pope Francis, The People's Pope. Time. Retrieved from http://poy.time.com/2013/12/11/person-of-the-yearpope-francis-the-peoples-pope/.

CNN (2019). The people's Pope: Francis Comes to America. CNN International Edition. Retrieved from http://edition.cnn.com/specials/world/pope-francis.

del Bosque, I. R., \& San Martín, H. (2008). Tourist satisfaction a cognitive-affective model. Annals of Tourism Research, 35(2), 551-573. 
Doyle, D. M. (1992). The church emerging from Vatican II: a popular approach to contemporary Catholicism. Mystic, CT: Twenty-Third Publications.

Echtner, C. M., \& Ritchie, J. B. (1993). The measurement of destination image: An empirical assessment. Journal of Travel Research, 31(4), 3-13.

Elkins, D. N., Hedstrom, L. J., Hughes, L. L., Leaf, J. A., \& Saunders, C. (1988). Toward a humanistic-phenomenological spirituality: Definition, description, and measurement. Journal of Humanistic Psychology, 28(4), 5-18.

Erdem, T., Swait, J., \& Louviere, J. (2002). The impact of brand credibility on consumer price sensitivity. International Journal of Research in Marketing, 19(1), 1-19.

Erdogan, B. Z. (1999). Celebrity endorsement: A literature review. Journal of Marketing Management, 15(4), 291-314.

Erdogan, B. Z., Baker, M. J., \& Tagg, S. (2001). Selecting celebrity endorsers: The practitioner's perspective. Journal of Advertising Research, 41(3), 39-48.

Fornell, C., \& Larcker, D. F. (1981). Structural equation models with unobservable variables and measurement error: Algebra and statistics. Journal of Marketing, 18(3), 382-388.

Gartner, W. C. (1994). Image formation process. Journal of Travel \& Tourism Marketing, 2(2-3), 191-216.

Gesler, W. (1996). Lourdes: healing in a place of pilgrimage. Health \& Place, 2(2), 95-105.

Glover, P. (2009). Celebrity endorsement in tourism advertising: Effects on destination image. Journal of Hospitality and Tourism Management, 16(1), 16-23.

Gorsuch, R. L., \& Shafranske, E. (1984). Factors associated with the perception of spirituality in psychotherapy. The Journal, 16(2), 231.

Guo, T. (2015). Spirituality'as reconceptualisation of the self: Alan Turing and his pioneering ideas on artificial intelligence. Culture and Religion, 16(3), 269-290.

Hair Jr, J. F., Hult, G. T. M., Ringle, C., \& Sarstedt, M. (2016). A primer on partial least squares structural equation modeling (PLS-SEM). Sage Publications.

Hair Jr, J. F., Sarstedt, M., Hopkins, L., \& Kuppelwieser, V. (2014). Partial least squares structural equation modeling (PLS-SEM) An emerging tool in business research. European Business Review, 26(2), 106-121.

Heelas, P. (2009). Spiritualities of life: New age romanticism and consumptive capitalism. John Wiley \& Sons.

Henseler, J., Ringle, C. M., \& Sarstedt, M. (2015). A new criterion for assessing discriminant validity in variance-based structural equation modeling. Journal of the Academy of Marketing Science, 43(1), 115-135.

Holbrook, M. B. (1978). Beyond attitude structure: Toward the informational determinants of attitude. Journal of Marketing Research, 15(4), 545-556.

Kamins, M. A., \& Gupta, K. (1994). Congruence between spokesperson and product type: A matchup hypothesis perspective. Psychology \& Marketing, 11(6), 569-586.

Kaplanidou, K., Jordan, J. S., Funk, D., \& Ridinger, L. L. (2012). Recurring sport events and destination image perceptions: Impact on active sport tourist behavioral intentions and place attachment. Journal of Sport Management, 26(3), 237-248.

Kim, S. (2012). Audience involvement and film tourism experiences: Emotional places, emotional experiences. Tourism Management, 33(2), 387-396.

Kim, S. S., Lee, J., \& Prideaux, B. (2014). Effect of celebrity endorsement on tourists' perception of corporate image, corporate credibility and corporate loyalty. International Journal of Hospitality Management, 37, 131-145. 
Kyle, G., Graefe, A., \& Manning, R. (2005). Testing the dimensionality of place attachment in recreational settings. Environment and Behavior, 37(2), 153-177.

Lanuza, G. M. (2017). Making and Selling the" Rock Star Pope": The Celebritization of Pope Francis during His Five-Day Visit to the Philippines. Humanities Diliman, 14(1), 1-45.

Lee, S., Scott, D., \& Kim, H. (2008). Celebrity fan involvement and destination perceptions. Annals of Tourism Research, 35(3), 809-832.

Li, X., \& Stepchenkova, S. (2012). Chinese outbound tourists' destination image of America: Part I. Journal of Travel Research, 51(3), 250-266.

Magnini, V. P., Garcia, C., \& Honeycutt Jr, E. D. (2010). Identifying the attributes of an effective restaurant chain endorser. Cornell Hospitality Quarterly, 51(2), 238-250.

Mazumdar, S., \& Mazumdar, S. (2004). Religion and place attachment: A study of sacred places. Journal of Environmental Psychology, 24(3), 385-397.

McCracken, G. (1989). Who is the celebrity endorser? Cultural foundations of the endorsement process. Journal of Consumer Research, 16(3), 310-321.

Misra, S., \& Beatty, S. E. (1990). Celebrity spokesperson and brand congruence: An assessment of recall and affect. Journal of Business Research, 21(2), 159-173.

Moore, R. L., \& Graefe, A. R. (1994). Attachments to recreation settings: The case of rail-trail users. Leisure Sciences, 16(1), 17-31.

Nunnally, J. C. (1978). Psychometric Theory: $2 d$ Ed. New York: McGraw-Hill.

Nunnally, J. C., \& Bernstein, I.H. (1994). Psychological theory. New York, NY: MacGraw-Hill, $131-147$.

Ohanian, R. (1990). Construction and validation of a scale to measure celebrity endorsers' perceived expertise, trustworthiness, and attractiveness. Journal of Advertising, 19(3), $39-52$.

Ohanian, R. (1991). The impact of celebrity spokespersons' perceived image on consumers' intention to purchase. Journal of Advertising Research, 31(1), 46-54.

Papal Visit (2015). Nine Ways People Participated in Pope Francis's 2015 US Visit. United States Conference of Catholic Bishops. Retrieved from http://www.usccb.org/about/leadership/holy-see/francis/papal-visit-2015/

Peelen, J., \& Jansen, W. (2007). Emotive movement on the road to Santiago de Compostela. Etnofoor, 75-96.

Petty, R. E. \& Cacioppo, J. T. (1986). Communication and persuasion. New York: Springer.

Piedmont, R. L. (1999). Does spirituality represent the sixth factor of personality? Spiritual transcendence and the five-factor model. Journal of Personality, 67(6), 985-1013.

Piedmont, R. L. (2001). Spiritual transcendence and the scientific study of spirituality. Journal of Rehabilitation, 67(1), 4-11.

Piedmont, R. L., Ciarrochi, J. W., Dy-Liacco, G. S., \& Williams, J. E. (2009). The empirical and conceptual value of the spiritual transcendence and religious involvement scales for personality research. Psychology of Religion and Spirituality, 1(3), 162.

Prayag, G., \& Ryan, C. (2012). Antecedents of tourists' loyalty to Mauritius: The role and influence of destination image, place attachment, personal involvement, and satisfaction. Journal of Travel Research, 51(3), 342-356.

Pringle, H. (2004). Celebrity sells. John Wiley \& Sons.

Ryan, C., Yanning, Z., Huimin, G., \& Song, L. (2009). Tourism, a Classic Novel, and Television: The Case of Cáo Xuěqin's Dream of the Red Mansions and Grand View Gardens, Beijing. Journal of Travel Research, 48(1), 14-28. 
Scannell, L., \& Gifford, R. (2010). Defining place attachment: A tripartite organizing framework. Journal of Environmental Psychology, 30(1), 1-10.

Sharpley, R. (2009). Tourism, religion and spirituality. The SAGE handbook of tourism studies, 237-253.

Sharpley, R., \& Sundaram, P. (2005). Tourism: A sacred journey? The case of ashram tourism, India. International Journal of Tourism Research, 7(3), 161-171.

Simpson, E. K., \& Kahler, R. C. (1981). A Scale for Source Credibility; Validated in the Selling Context. Journal of Personal Selling \& Sales Management, 1(1), 17-25.

Solmoe Shrine. (2018). Statistics of the number of visitors in Solmoe Shrine. Solmoe Shrine: Author.

Solmoe Shrine. (2019). Introduction of Solmoe Shrine. Retrieved from http://www.solmoe.or.kr/.

Till, B. D., Stanley, S. M., \& Priluck, R. (2008). Classical conditioning and celebrity endorsers: An examination of belongingness and resistance to extinction. Psychology \& Marketing, 25(2), 179-196.

Ulvoas-Moal, G. (2010). Exploring the influence of spirituality: A new perspective on senior consumers' behavior. ACR North American Advances, 37, 917-919.

van der Veen, R., \& Song, H. (2010). Exploratory study of the measurement scales for the perceived image and advertising effectiveness of celebrity endorsers in a tourism context. Journal of Travel \& Tourism Marketing, 27(5), 460-473.

van der Veen, R., \& Song, H. (2014). Impact of the perceived image of celebrity endorsers on tourists' intentions to visit. Journal of Travel Research, 53(2), 211-224.

Veasna, S., Wu, W. Y., \& Huang, C. H. (2013). The impact of destination source credibility on destination satisfaction: The mediating effects of destination attachment and destination image. Tourism Management, 36, 511-526.

Williams, D. R., Patterson, M. E., Roggenbuck, J. W., \& Watson, A. E. (1992). Beyond the commodity metaphor: Examining emotional and symbolic attachment to place. Leisure Sciences, 14(1), 29-46.

Williams, D. R., \& Vaske, J. J. (2003). The measurement of place attachment: Validity and generalizability of a psychometric approach. Forest Science, 49(6), 830-840.

Willson, G. B., McIntosh, A. J., \& Zahra, A. L. (2013). Tourism and spirituality: A phenomenological analysis. Annals of Tourism Research, 42, 150-168.

Wong, J. Y., \& Lai, T. C. (2015). Celebrity attachment and behavioral intentions: The mediating role of place attachment. International Journal of Tourism Research, 17(2), 161-170.

Yen, C. H., \& Croy, W. G. (2016). Film tourism: Celebrity involvement, celebrity worship and destination image. Current Issues in Tourism, 19(10), 1027-1044. 
Figure 1 Meaning transfer in celebrity endorsement

Culture
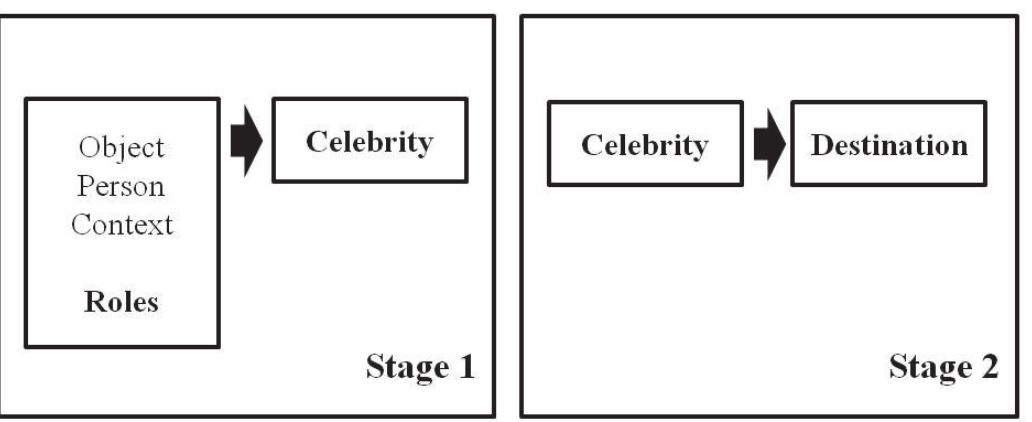

Note: 1) adapted from a study of McCracken (1989)
2) $\Rightarrow$ indicates the path of meaning movement
3) $\square$ indicates each stage of meaning movement
Perception

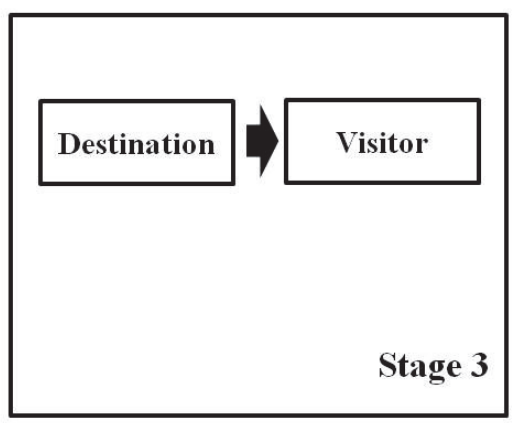


Figure 2 Visitor numbers at Solmoe Shrine (2009-2017)

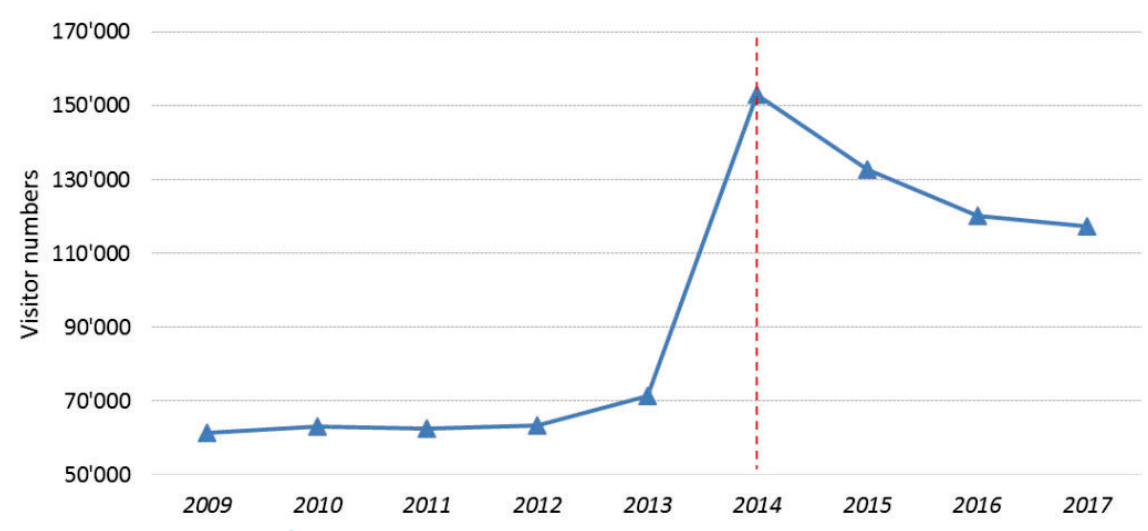


Table 1 Profiles of the respondents $(N=337)$

\begin{tabular}{|c|c|c|c|c|c|}
\hline Category & $N$ & $\%$ & Category & $N$ & $\%$ \\
\hline Gender & & & (to be continued) & & \\
\hline M & 83 & 24.6 & Professional & 13 & 3.9 \\
\hline $\mathrm{F}$ & 253 & 75.1 & Housewife/husband & 13 & 3.9 \\
\hline Marital status & & & Businessman/woman & 19 & 5.6 \\
\hline Single & 37 & 11.0 & Company employee & 3 & .9 \\
\hline Married & 298 & 88.4 & Civil servant & 176 & 52.2 \\
\hline Other & 2 & .6 & Retired & 11 & 3.3 \\
\hline Age & & & Other & 35 & 13.4 \\
\hline$<20$ & 1 & .3 & Income & & \\
\hline $20-29$ & 10 & 3.0 & Under $\$ 20,000$ & 73 & 21.7 \\
\hline $30-39$ & 23 & 6.8 & $\$ 20,001-30,000$ & 52 & 15.4 \\
\hline $40-49$ & 59 & 17.5 & $\$ 30,001-40,000$ & 84 & 24.9 \\
\hline $50-59$ & 72 & 21.4 & $\$ 40,001-50,000$ & 29 & 8.6 \\
\hline $60-69$ & 116 & 34.4 & $\$ 50,001-60,000$ & 35 & 10.4 \\
\hline$>70$ & 56 & 16.6 & $\$ 60,001-70,000$ & 13 & 3.9 \\
\hline Education & & & Over $\$ 70,001$ & 51 & 15.1 \\
\hline High school graduate & 102 & 30.3 & & & \\
\hline University student & 27 & 8.0 & Religious belief & & \\
\hline University graduate & 164 & 48.7 & Not very religious & 5 & 1.5 \\
\hline Postgraduate & 44 & 13.1 & Religious & 12 & 3.6 \\
\hline Occupation & & & Neutral & 91 & 27.0 \\
\hline Student & 29 & 8.6 & Religious & 177 & 52.5 \\
\hline Service/sales & 28 & 8.3 & Very religious & 52 & 15.4 \\
\hline
\end{tabular}


Table 2 Travel experience related to the Pope's visit

\begin{tabular}{|c|c|c|c|c|c|}
\hline Category & $N$ & $\%$ & Category & $N$ & $\%$ \\
\hline Aware of purpose of the & & & (to be continued) & & \\
\hline \multicolumn{6}{|l|}{ Pope visit } \\
\hline $\mathrm{Y}^{*}$ & 243 & 72.1 & Visit experience & & \\
\hline $\mathrm{N}$ & 78 & 23.1 & Once & 154 & 45.7 \\
\hline Unreported & 16 & 4.7 & Twice & 95 & 28.2 \\
\hline $\begin{array}{l}\text { Aware of the Shrine after the } \\
\text { Pope visit }\end{array}$ & & & Three times & 41 & 12.2 \\
\hline $\mathrm{Y}^{1}$ & 129 & 38.3 & Four times & 15 & 4.5 \\
\hline $\mathrm{N}$ & 203 & 60.2 & Five times or more & 32 & 9.5 \\
\hline Unreported & 5 & 1.5 & Visit purpose & & \\
\hline $\begin{array}{l}\text { Whether visited the Shrine } \\
\text { before the Pope visit }\end{array}$ & & & Pilgrimage (retreat) & 299 & 88.7 \\
\hline $\mathrm{Y}$ & 150 & 44.5 & Tourism & 29 & 8.6 \\
\hline \multirow[t]{2}{*}{$\mathrm{N}$} & 185 & 54.9 & Others & 9 & 2.7 \\
\hline & 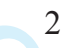 & .6 & Travel motivations & Mean & S.D. \\
\hline $\begin{array}{l}\text { Aware of the historical } \\
\text { importance of the Shrine }\end{array}$ & & & Mo1 & 5.89 & 1.574 \\
\hline Y & 269 & 79.8 & Mo2 & 5.88 & 1.568 \\
\hline \multirow[t]{2}{*}{$\mathrm{N}$} & 52 & 15.4 & Mo3 & 5.72 & 1.697 \\
\hline & 16 & 4.7 & Mo4 & 5.55 & 1.725 \\
\hline
\end{tabular}


Table 3 Reliability of the constructs

\begin{tabular}{|c|c|c|c|c|}
\hline Construct & $\begin{array}{r}\text { Factor } \\
\text { loading }\end{array}$ & rho_A & $\begin{array}{c}\text { Composite } \\
\text { reliability }\end{array}$ & Cronbach's $\alpha$ \\
\hline Celebrity trustworthiness (CT) & & .989 & .992 & .989 \\
\hline Sincere & $.976^{* * *}$ & & & \\
\hline Trustworthy & $.988^{* * *}$ & & & \\
\hline Reliable & $.979^{* * *}$ & & & \\
\hline Honest & $.978^{* * *}$ & & & \\
\hline Dependable & $.976^{* * *}$ & & & \\
\hline Celebrity expertise (CE) & & .963 & .971 & .963 \\
\hline Knowledgeable & $.910^{* * *}$ & & & \\
\hline Qualified & $.925^{* * *}$ & & & \\
\hline Expert & $.946^{* * *}$ & & & \\
\hline Skilled & $.943^{* * *}$ & & & \\
\hline Experienced & $.939^{* * *}$ & & & \\
\hline Celebrity attractiveness ( $C A)$ & & .956 & .968 & .956 \\
\hline Attractive & $.941^{* * *}$ & & & \\
\hline Classy & $.929^{* * *}$ & & & \\
\hline Elegant & $.944^{* * *}$ & & & \\
\hline Good-looking & $.943^{* * *}$ & & & \\
\hline Spirituality (SP) & & .955 & .961 & .954 \\
\hline Fulfillment and bliss & $.792^{* * *}$ & & & \\
\hline Inner strength and/or peace & $.864^{* * *}$ & & & \\
\hline Spiritual plane of consciousness & $.859^{* * *}$ & & & \\
\hline Step outside of ambitions and failures & $.872^{* * *}$ & & & \\
\hline Distraction from my prayers & $.858^{* * *}$ & & & \\
\hline Share common bond & $.875^{* * *}$ & & & \\
\hline Plane of consciousness or spirituality & $.868^{* * *}$ & & & \\
\hline Emotional bond with all of humanity & $.849^{* * *}$ & & & \\
\hline Meaning to life & $.855^{* * *}$ & & & \\
\hline Destination image (DI) & & .940 & .941 & .927 \\
\hline Distressing & $.793^{* * *}$ & & & \\
\hline Gloomy & $.836^{* * *}$ & & & \\
\hline Dull & $.803^{* * *}$ & & & \\
\hline Inhospitable & $.892^{* * *}$ & & & \\
\hline Unfamiliar & $.869^{* * *}$ & & & \\
\hline Non family-oriented & $.872^{* * *}$ & & & \\
\hline Unfamous & $.759^{* * *}$ & & & \\
\hline Destination attachment (DA) & & .961 & .965 & .960 \\
\hline Shrine means a lot to me & $.801^{* * *}$ & & & \\
\hline Connection to the Shrine & $.827^{* * *}$ & & & \\
\hline Tell many people about this trip & $.871^{* * *}$ & & & \\
\hline Bring children or acquaintances & $.847^{* * *}$ & & & \\
\hline Meaningful to visit the Shrine & $.791^{* * *}$ & & & \\
\hline Identity is tied to my visit & $.806^{* * *}$ & & & \\
\hline Committed to the Shrine & $.832^{* * *}$ & & & \\
\hline Enjoyed visiting the Shrine & $.882^{* * *}$ & & & \\
\hline Satisfaction out of visiting the Shrine & $.884^{* * *}$ & & & \\
\hline Visiting the Shrine is important & $.868^{* * *}$ & & & \\
\hline Wouldn't substitute doing & $.770^{* * *}$ & & & \\
\hline Fond memories of the Shrine & $.823^{* * *}$ & & & \\
\hline Eudaimonia (EM) & & .932 & .956 & .932 \\
\hline Worthwhile & $.939^{* * *}$ & & & \\
\hline
\end{tabular}




\begin{tabular}{ll}
\hline Accomplishment & $.936^{* * *}$ \\
Meaningful & $.939^{* * *}$ \\
\hline Note: ${ }^{* * *} p<.001$. &
\end{tabular}


Table 4 Validity of the reflective constructs

\begin{tabular}{lrrrrrrr}
\hline & CT & CE & CA & SP & DI & DA & EM \\
\hline CT & $(.980)$ & & & & & & \\
CE & .881 & $(.933)$ & & & & & \\
CA & .927 & .933 & $(.939)$ & & & & \\
SP & .412 & .421 & .393 & $(.855)$ & & & \\
DI & .310 & .325 & .330 & .355 & $(.833)$ & & \\
DA & .370 & .391 & .370 & .678 & .433 & $(.834)$ & .724 \\
EM & .298 & .302 & .290 & .609 & .421 & & \\
AVE & .960 & .870 & .882 & .731 & .694 & .696 & .880 \\
\hline
\end{tabular}

Note: Values in parentheses are the square root of the AVEs of the corresponding constructs. $\mathrm{EM}=$ Eudaimonia, $\mathrm{DA}=$ Destination attachment, $\mathrm{DI}=$ Destination image, $\mathrm{SP}=$ Spirituality, $\mathrm{CA}=$ Celebrity attractiveness, $\mathrm{CE}=$ Celebrity expertise, and $\mathrm{CT}=$ Celebrity trustworthiness. 
Table 5 Discriminant validity assessment using heterotrait-monotrait ratio (HTMT)

\begin{tabular}{|c|c|c|c|c|c|c|}
\hline & $\mathrm{CT}$ & $\mathrm{CE}$ & $\mathrm{CA}$ & SP & DI & $\mathrm{DA}$ \\
\hline \multirow[t]{2}{*}{$\mathrm{CE}$} & .901 & & & & & \\
\hline & {$[.837, .944]$} & & & & & \\
\hline \multirow[t]{2}{*}{$\mathrm{CA}$} & .953 & .972 & & & & \\
\hline & {$[.925, .971]$} & {$[.950, .989]$} & & & & \\
\hline \multirow[t]{2}{*}{$\mathrm{SP}$} & .422 & .437 & .410 & & & \\
\hline & {$[.288, .545]$} & {$[.310, .555]$} & {$[.277, .536]$} & & & \\
\hline \multirow[t]{2}{*}{ DI } & .319 & .336 & .345 & .371 & & \\
\hline & {$[.187, .459]$} & {$[.202, .477]$} & {$[.213, .483]$} & {$[.259, .480]$} & & \\
\hline \multirow[t]{2}{*}{ DA } & .378 & .405 & .385 & .705 & .444 & \\
\hline & {$[.233, .513]$} & {$[.269, .529]$} & {$[.245, .512]$} & {$[.624, .775]$} & {$[.331, .555]$} & \\
\hline \multirow[t]{2}{*}{ EM } & .310 & .318 & .308 & .645 & .443 & .765 \\
\hline & {$[.175, .443]$} & {$[.191, .438]$} & {$[.175, .434]$} & {$[.555, .726]$} & {$[.321, .562]$} & {$[.692, .831]$} \\
\hline
\end{tabular}

Notes: The results marked in bold indicate discriminant validity problems according to the $\mathrm{HTMT}_{90}$ criterion; $\mathrm{HTMT}_{\text {inference }}$ does not indicate discriminant validity problems.

$\mathrm{EM}=$ Eudaimonia, $\mathrm{DA}=$ Destination attachment, $\mathrm{DI}=$ Destination image, $\mathrm{SP}=$ Spirituality, $\mathrm{CA}=$ Celebrity attractiveness, $\mathrm{CE}=$ Celebrity expertise, and $\mathrm{CT}=$ Celebrity trustworthiness . 
Table 6 Path estimates

\begin{tabular}{|c|c|c|c|}
\hline Path & Estimate & S.E. & Confidence interval 95\% \\
\hline $\mathrm{CT} \rightarrow \mathrm{CA}$ & $.470^{* * *}$ & .038 & {$[.388, .538]$} \\
\hline $\mathrm{CT} \rightarrow \mathrm{SP}$ & .294 & .167 & {$[-.058, .596]$} \\
\hline $\mathrm{CT} \rightarrow \mathrm{DI}$ & -.065 & .127 & {$[-.329, .172]$} \\
\hline $\mathrm{CT} \rightarrow \mathrm{DA}$ & -.015 & .108 & {$[-.224, .196]$} \\
\hline $\mathrm{CE} \rightarrow \mathrm{CA}$ & $.519^{* * *}$ & .036 & {$[.452, .595]$} \\
\hline $\mathrm{CE} \rightarrow \mathrm{SP}$ & $.388^{*}$ & .166 & {$[.091, .731]$} \\
\hline $\mathrm{CE} \rightarrow \mathrm{DI}$ & .024 & .120 & {$[-.187, .289]$} \\
\hline $\mathrm{CE} \rightarrow \mathrm{DA}$ & .087 & .099 & {$[-.111, .283]$} \\
\hline $\mathrm{CA} \rightarrow \mathrm{SP}$ & -.242 & .209 & {$[-.647, .158]$} \\
\hline $\mathrm{CA} \rightarrow \mathrm{DI}$ & .262 & .143 & {$[-.007, .560]$} \\
\hline $\mathrm{CA} \rightarrow \mathrm{DA}$ & .012 & .134 & {$[-.256, .269]$} \\
\hline $\mathrm{SP} \rightarrow \mathrm{DI}$ & $.268^{* * *}$ & .059 & {$[.154, .386]$} \\
\hline $\mathrm{SP} \rightarrow \mathrm{DA}$ & $.570^{* * *}$ & .052 & {$[.465, .663]$} \\
\hline $\mathrm{SP} \rightarrow \mathrm{EM}$ & $.206^{* *}$ & .060 & {$[.086, .321]$} \\
\hline $\mathrm{DI} \rightarrow \mathrm{DA}$ & $.203^{* * *}$ & .055 & {$[.100, .315]$} \\
\hline $\mathrm{DI} \rightarrow \mathrm{EM}$ & $.117^{*}$ & .050 & {$[.023, .221]$} \\
\hline $\mathrm{DA} \rightarrow \mathrm{EM}$ & $.534^{* * *}$ & .064 & {$[.403, .658]$} \\
\hline
\end{tabular}

Notes: $\mathrm{EM}=$ Eudaimonia, DA = Destination attachment, DI = Destination image, $\mathrm{SP}=$ Spirituality, CA = Celebrity attractiveness, $\mathrm{CE}=$ Celebrity expertise, and $\mathrm{CT}=$ Celebrity trustworthiness. $R^{2}$ : CA: .920; DA: .507; DI: .169; EM: .562; SP: .189.

${ }^{* *} p<.01,{ }^{* * *} p<.001$. 
Table 7 Values of $f^{2}$ size

\begin{tabular}{lccccccc}
\hline & CT & CE & CA & SP & DI & DA & EM \\
\hline CT & .000 & .000 & $\mathbf{. 6 2 2}$ & .015 & .001 & .000 & .000 \\
CE & .000 & .000 & $\mathbf{. 7 5 7}$ & $\mathbf{. 0 2 4}$ & .000 & .002 & .000 \\
CA & .000 & .000 & .000 & .006 & .007 & .000 & .000 \\
SP & .000 & .000 & .000 & .000 & $\mathbf{. 0 7 0}$ & $\mathbf{. 5 0 0}$ & $\mathbf{. 0 5 2}$ \\
DI & .000 & .000 & .000 & .000 & .000 & $\mathbf{. 0 6 9}$ & $\mathbf{. 0 2 5}$ \\
DA & .000 & .000 & .000 & .000 & .000 & .000 &. $\mathbf{3 2 5}$ \\
EM & .000 & .000 & .000 & .000 & .000 & .000 & .000 \\
\hline
\end{tabular}

Notes: $\mathrm{EM}=$ Eudaimonia, $\mathrm{DA}=$ Destination attachment, $\mathrm{DI}=$ Destination image, $\mathrm{SP}=$ Spirituality, $\mathrm{CA}=$ Celebrity attractiveness, $\mathrm{CE}=$ Celebrity expertise, and $\mathrm{CT}=$ Celebrity trustworthiness . 
Table 8 Total indirect effects

\begin{tabular}{|c|c|c|c|c|}
\hline & $\begin{array}{r}\text { Original Sample } \\
(\mathrm{O})\end{array}$ & $\begin{array}{r}\text { Standard Deviation } \\
\text { (STDEV) }\end{array}$ & $\begin{array}{r}\text { T Statistics } \\
(|\mathrm{O} / \mathrm{STDEV}|)\end{array}$ & P Values \\
\hline \multicolumn{5}{|l|}{ CT: } \\
\hline $\mathrm{CT} \rightarrow \mathrm{SP}$ & -.114 & .098 & 1.163 & .245 \\
\hline $\mathrm{CT} \rightarrow \mathrm{DI}$ & $.172^{*}$ & .082 & 2.100 & .036 \\
\hline $\mathrm{CT} \rightarrow \mathrm{DA}$ & .130 & .109 & 1.189 & .234 \\
\hline $\mathrm{CT} \rightarrow \mathrm{EM}$ & .111 & .102 & 1.084 & .278 \\
\hline \multicolumn{5}{|l|}{ CE: } \\
\hline $\mathrm{CE} \rightarrow \mathrm{SP}$ & -.126 & .110 & 1.139 & .255 \\
\hline $\mathrm{CE} \rightarrow \mathrm{DI}$ & $.207^{*}$ & .086 & 2.400 & .016 \\
\hline $\mathrm{CE} \rightarrow \mathrm{DA}$ & .203 & .114 & 1.784 & .074 \\
\hline $\mathrm{CE} \rightarrow \mathrm{EM}$ & $.236^{*}$ & .093 & 2.530 & .011 \\
\hline \multicolumn{5}{|l|}{ CA: } \\
\hline $\mathrm{CA} \rightarrow \mathrm{DI}$ & -.065 & .060 & 1.081 & .280 \\
\hline $\mathrm{CA} \rightarrow \mathrm{DA}$ & -.098 & .139 & .704 & .482 \\
\hline $\mathrm{CA} \rightarrow \mathrm{EM}$ & -.072 & .132 & .549 & .583 \\
\hline \multicolumn{5}{|l|}{ SP: } \\
\hline $\mathrm{SP} \rightarrow \mathrm{DA}$ & $.054^{* *}$ & .020 & 2.686 & .007 \\
\hline $\mathrm{SP} \rightarrow \mathrm{EM}$ & $.365^{* * *}$ & .044 & 8.280 & .000 \\
\hline \multicolumn{5}{|l|}{ DI: } \\
\hline $\mathrm{DI} \rightarrow \mathrm{EM}$ & $.108^{* *}$ & .034 & 3.167 & .002 \\
\hline
\end{tabular}

Notes: $\mathrm{EM}=$ Eudaimonia, DA $=$ Destination attachment, $\mathrm{DI}=$ Destination image, $\mathrm{SP}=$ Spirituality, $\mathrm{CA}=$ Celebrity attractiveness, $\mathrm{CE}=$ Celebrity expertise, and $\mathrm{CT}=$ Celebrity trustworthiness. ${ }^{*} p<.05,{ }^{* *} p<.01,{ }^{* * *} p<.001$. 
Table 9 Specific indirect effects

\begin{tabular}{|c|c|c|c|c|}
\hline & $\begin{array}{r}\text { Original } \\
\text { Sample }(\mathrm{O}) \\
\end{array}$ & $\begin{array}{r}\text { Standard Deviation } \\
\text { (STDEV) }\end{array}$ & $\begin{array}{r}\text { T Statistics } \\
(|\mathrm{O} / \mathrm{STDEV}|)\end{array}$ & P Values \\
\hline \multicolumn{5}{|l|}{ CT: } \\
\hline $\mathrm{CT} \rightarrow \mathrm{CA} \rightarrow \mathrm{DI}$ & $.123^{*}$ & .068 & 1.815 & .070 \\
\hline $\mathrm{CT} \rightarrow \mathrm{SP} \rightarrow \mathrm{DI}$ & .079 & .050 & 1.591 & .112 \\
\hline $\mathrm{CT} \rightarrow \mathrm{SP} \rightarrow \mathrm{DA}$ & $.168^{*}$ & .096 & 1.748 & .081 \\
\hline $\mathrm{CT} \rightarrow \mathrm{SP} \rightarrow \mathrm{EM}$ & .060 & .040 & 1.513 & .130 \\
\hline $\mathrm{CT} \rightarrow \mathrm{SP} \rightarrow \mathrm{DA} \rightarrow \mathrm{EM}$ & $.090^{*}$ & .051 & 1.746 & .081 \\
\hline \multicolumn{5}{|l|}{$\mathrm{CE}:$} \\
\hline $\mathrm{CE} \rightarrow \mathrm{CA} \rightarrow \mathrm{DI}$ & $.136^{*}$ & .076 & 1.802 & .072 \\
\hline $\mathrm{CE} \rightarrow \mathrm{SP} \rightarrow \mathrm{DI}$ & $.104^{* *}$ & .053 & 1.982 & .048 \\
\hline $\mathrm{CE} \rightarrow \mathrm{SP} \rightarrow \mathrm{DA}$ & $.221^{* *}$ & .097 & 2.279 & .023 \\
\hline $\mathrm{CE} \rightarrow \mathrm{SP} \rightarrow \mathrm{EM}$ & $.080^{*}$ & .042 & 1.912 & .056 \\
\hline $\mathrm{CE} \rightarrow \mathrm{SP} \rightarrow \mathrm{DA} \rightarrow \mathrm{EM}$ & $.118^{* *}$ & .054 & 2.180 & .029 \\
\hline
\end{tabular}

